\title{
UPAYA MENINGKATKAN KOMPETENSI BELAJAR PPKN MATERI PEMBUKAAN UUD 1945 DENGAN METODE MAKE A MATCH PADA SISWA KELAS IX SMP NEGERI 3 COLOMADU SEMESTER 1 TAHUN PELAJARAN 2019/2020
}

\author{
Supanti \\ SMP Negeri 3 Colomadu \\ Email : supanti1969@gmail.com
}

\begin{abstract}
Abstrak : Background of the lack of active involvement of students in learning there are at least three indicators that indicate this. First, students lack the courage to express opinions to others. Second, students lack the ability to formulate their own ideas. and third, students are not accustomed to competing to express their opinions with other friends. These problems eventually led to the achievement of student learning competencies to be low. The problems examined were formulated as follows: how is the effort to improve the learning competence of PPKn in the opening of the 1945 Constitution with the Make A Match method in class IX students of SMP Negeri 3 Colomadu Karanganyar Semester 1 2019/2020 Academic Year. This research method uses a classroom action research model (CAR). The subjects in this study were all students of class IX SMPN 3 Colomadu in Academic Year 2019/2020. Data collection techniques using observation, questionnaires, and documentation. Data analysis techniques using comparative analysis and critical analysis. The results showed that the implementation of learning using the Make A Match method could improve the PPKn learning competence in the Opening of the 1945 Constitution in class IX students of SMP Negeri 3 Colomadu Karanganyar Semester 1 2019/2020 Academic Year. Student knowledge competence at the end of the second cycle reaches an average of 85.8, has exceeded the established performance indicators that is equal to 80. Attitude competence at the end of the second cycle reaches an average of 3.4 (active attitude) and student skills competency at the end of the cycle II reached an average of 89.1 (very good), so this action research was declared successful. Achievement of performance indicators in cycle II shows that the application of the Make A Match learning method is effective in increasing student learning competency. The suggestion for PPKn teachers is that they need to increase their knowledge about the variety of learning methods. This will help the teacher to be able to improve the quality of the process and student learning outcomes in the learning process. The use of the Make A Match learning method can be an alternative to increasing learning effectiveness.
\end{abstract}

Keywords: Learning Competence, Make A Match

\section{PENDAHULUAN}

Pendidikan Pancasila dan Kewarganegaraan (PPKn) merupakan salah satu muatan kurikulum pendidikan dasar dan menengah yang dimaksudkan untuk membentuk siswa menjadi manusia yang memiliki rasa kebangsaan dan cinta tanah air. Mata pelajaran PPKn diharapkan menjadi wahana edukatif dalam mengembangkan siswa menjadi manusia yang memiliki rasa kebangsaan dan cinta tanah air, yang dijiwai oleh nilai-nilai Pancasila, 
Undang-Undang Dasar Negara Republik Indonesia Tahun 1945, semangat Bhinneka Tunggal Ika, dan komitmen Negara Kesatuan Republik Indonesia (Sumartini dan Putra, 2018: 4).

Tujuan mata pelajaran PPKn pada jenjang pendidikan dasar dan menengah adalah mengembangkan kompetensi belajar siswa di seluruh dimensi kewarganegaraan, yakni kompetensi sikap kewarganegaraan (afektif), pengetahuan kewarganegaraan (kognitif), dan keterampilan kewarganegaraan termasuk partisipasi kewarganegaraan (psikomotorik). Hal ini berarti tujuan pelajaran PPKn adalah untuk membentuk siswa menjadi warga negara Indonesia yang cerdas serta bersikap dan berperilaku yang baik dan bertanggungjawab. Agar tujuan pencapaian kompetensi belajar tersebut dapat tercapai, kegiatan pembelajaran pada mata pelajaran PPKn perlu menggunakan prinsip pembelajaran yang berpusat pada siswa, mengembangkan kreativitas siswa, menciptakan kondisi menyenangkan dan menantang, bermuatan nilai, etika, estetika, logika, dan kinestetika, dan menyediakan pengalaman belajar yang beragam melalui penerapan berbagai strategi dan metode pembelajaran yang menyenangkan, kontekstual, efektif, efsien, dan bermakna.

Kondisi riil pada siswa kelas IX di SMP Negeri 3 Colomadu Kabupaten Karanganyar menunjukkan bahwa sebagian besar siswa belum mampu mencapai kompetensi belajar yang diinginkan. Nilai rata-rata hasil belajar PPKn siswa hanya mencapai sebesar 67, lebih rendah dari nilai KKM sebesar 80. Berdasarkan hasil observasi di kelas IX SMPN 3 Colomadu ditemukan berbagai permasalahan sebagai berikut: siswa kurang memperhatikan penjelasan guru, banyak siswa yang belum paham dengan penjelasan guru, kurangnya keterlibatan aktif siswa dalam proses pembelajaran, serta kurangnya kesadaran siswa tentang pentingnya belajar PPKn.

Kondisi tersebut menunjukkan bahwa terdapat beberapa masalah yang dapat mempengaruhi pencapaian kompetensi belajar PPKn siswa. Siswa yang kurang fokus pada pelajaran, kurangnya keterlibatan aktif siswa dalam proses pembelajaran, serta kurangnya kesadaran siswa tentang pentingnya belajar PPKn dapat menurunkan minat siswa dalam mengikuti kegiatan pembelajaran PPKn. Aktivitas siswa hanya mendengarkan dan mencatat penjelasan guru. Sementara pembelajaran saintifik yang sesuai arahan Kurikulum 2013 belum berjalan dengan optimal.

Kurangnya keterlibatan aktif siswa dalam pembelajaran setidaknya ada tiga indiktor yang menunjukkan hal ini. Pertama, siswa kurang memiliki keberanian untuk menyampaikan pendapat kepada orang lain. Kedua, siswa kurang memiliki kemampuan untuk merumuskan gagasan sendiri. dan ketiga, siswa belum terbiasa bersaing menyampaikan pendapat dengan teman yang lain. Masalah-masalah tersebut akhirnya berujung pada pencapaian kompetensi belajar siswa menjadi rendah.

Berbagai permasalahan tersebut harus segera diatasi. Guru perlu merancang suatu model pembelajaran yang tidak membosankan dan menarik minat dan perhatian siswa agar dapat tercipta suasana pembelajaran yang menyenangkan. Model pembelajaran yang dikembangkan harus sesuai dengan karakteristik PPKn secara utuh dalam rangka peningkatan kualitas belajar. Model pembelajaran juga harus berorientasi pada pengembangan karakter siswa sebagai warga negara yang cerdas dan baik secara utuh dalam proses pembelajaran autentik (authentic instructional and authentic learning) dalam bingkai 
integrasi kompetensi sikap, pengetahuan, dan keterampilan. Selain itu model pembelajaran yang mengarahkan siswa bersikap dan berpikir ilmiah (scientifc), yaitu pembelajaran yang mendorong dan menginspirasi siswa berpikir secara kritis, analistis, dan tepat dalam mengidentifkasi, memahami, memecahkan masalah, dan mengaplikasikan materi pembelajaran

Salah satu model pembelajaran yang sangat melibatkan siswa dalam proses belajar, adalah model pembelajaran kooperatif. Model pembelajaran kooperatif (cooperative learning) merupakan bentuk pembelajaran dengan cara siswa belajar dan bekerja dalam kelompok-kelompok kecil secara kolaboratif yang anggotanya terdiri dari empat sampai enam dengan struktur kelompok yang bersifat heterogen (Rusman, 2014: 202). Proses pembelajaran kooperatif lebih menekankan pada kerja sama dalam kelompok. Selain dapat meningkatkan kemampuan kognitif siswa, juga dapat meningkatkan sikap tolong-menolong siswa, belajar untuk saling tukar pendapat, membiasakan diri untuk berani berpendapat dan belajar menghargai pendapat orang lain.

Terdapat beberapa metode yang dapat diterapkan dalam model belajar kooperatif, seperti: make a match, guided note taking, jigsaw dan sebagainya. Model pembelajaran make a match (membuat pasangan) merupakan salah satu jenis metode pembelajaran kooperatif yang dikembangkan oleh Lorna Curran (dalam Rusman, 2014: 206). Model pembelajaran kooperatif dengan metode make a match menggunakan media berupa kartu yang berisi soal/jawaban dari materi yang dipelajari. Siswa diminta untuk mencari pasangan (soal dan jawaban) dari masing-masing kartu tersebut

Melalui metode make a match ini diharapkan siswa lebih aktif dalam pembelajaran sehingga kompetensi belajar bisa tercapai dengan maksimal. Keunggulan metode ini adalah siswa mencari pasangan sambil belajar mengenai suatu konsep atau topik dalam suasana menyenangkan. Kegiatan-kegiatan ini akan lebih mendorong siswa untuk lebih termotivasi dalam belajar, aktif mencari sumber rujukan dalam materi pelajaran, mencoba memahami, kemudian belajar untuk saling berdiskusi, membiasakan diri untuk mengemukakan pendapat, dan menghargai pendapat orang lain.

Berdasarkan latar belakang tersebut maka perlu diadakan penelitian dengan judul: "Upaya Meningkatkan Kompetensi Belajar PPKn Materi Pembukaan UUD 1945 dengan Metode Make A Match pada Siswa Kelas IX SMP Negeri 3 Colomadu Karanganyar Semester 1 Tahun Pelajaran 2019/2020.”

Permasalahan penelitian dirumuskan sebagai berikut: bagaimanakah upaya meningkatkan kompetensi belajar PPKn materi Pembukaan UUD 1945 dengan metode Make A Match pada siswa kelas IX SMP Negeri 3 Colomadu Karanganyar Semester 1 Tahun Pelajaran 2019/2020?

\section{LANDASAN TEORI}

a. Kompetensi Belajar

Yamin (2016: 126) menyatakan kompetensi adalah kemampuan dasar yang dapat dilakukan oleh siswa pada tahap pengetahuan, ketrampilan dan sikap. Kemampuan dasar ini akan dijadikan sebagai landasan melakukan proses pembelajaran dan penilaian siswa. 
Kompetensi merupakan kemampuan seseorang yang dapat terobservasi mencakup pengetahuan, keterampilan dan sikap kerja dalam menyelesaikan suatu pekerjaan atau tugas sesuai standar kompetensi yang ditetapkan.

Kurikulum 2013 menjelaskan bahwa kompetensi adalah kemampuan yang dapat dilakukan oleh siswa, yang mencakup pengetahuan, keterampilan, sikap dan perilaku. Berkaitan dengan perumusan tersebut, maka kompetensi dapat dikenali melalui sejumlah hasil belajar dan indikator yang dapat diukur dan diamati. Kompetensi yang dimaksud adalah pengetahuan (kognitif), sikap dan nilai-nilai (afektif) dan keterampilan (psikomotorik) yang diwujudkan dalam kebiasaan berpikir dan bertindak sehingga mampu menghadapi persoalan yang dialami. Kemampuan ini akan dijadikan sebagai landasan melakukan proses pembelajaran dan penilaian siswa.

Berdasarkan beberapa pengertian di atas, dapat disimpulkan bahwa kompetensi belajar adalah kemampuan yang dimiliki dan ditunjukkan siswa yang mencakup pengetahuan, keterampilan, sikap dan nilai-nilai yang diwujudkan dalam kebiasaan berfikir dan bertindak sebagai hasil belajar.

Menurut Permendikbud No. 23 Tahun 2016 tentang Standar Penilaian Pendidikan menyebutkan bahwa penilaian peserta didik harus meliputi sikap, pengetahuan, dan keterampilan baik selama proses (formatif) maupun pada akhir periode pembeajaran (sumatif).

b. Model Pembelajaran Make A Match

Model pembelajaran kooperatif Make A Match dikembangkan oleh Lorna Curron. Model ini bisa diterapkan untuk semua mata pelajaran dan tingkatan kelas. Menurut Rusman (2014: 223) model pembelajaran kooperatif teknik Make A Match adalah teknik pembelajaran kooperatif dengan cara mencari pasangan soal atau jawaban yang tepat, peserta didik yang sudah menemukan pasangannya sebelum batas waktu dan peserta didik yang dapat mencocokkan kartunya akan mendapat poin.

Pembelajaran Make A Match adalah satu model pembelajaran kooperatif di mana siswa mencari pasangan kartu sambil belajar mengenai suatu konsep atau topik dalam suasana menyenangkan. Dengan cara demikian akan memberi kesempatan siswa untuk bekerja sama dengan orang lain (Lie, 2010: 55). Tujuan dari pembelajaran dengan model Make A Match adalah untuk melatih peserta didik agar lebih cermat dan lebih kuat pemahamannya terhadap suatu materi pokok. Siswa dilatih berpikir cepat dan menghafal cepat sambil menganalisis dan berinteraksi sosial. Model pembelajaran Make A Match merupakan model yang menciptakan hubungan baik antara guru dan siswa. Guru mengajak siswa bersenang-senang dalam permainan. Kesenangan tersebut pun mengenai materi dan siswa dapat belajar secara langsung.

Hamdayama (2017: 109) langkah-langkah metode make a match sebagai berikut: (1) Guru menyiapkan beberapa kartu yang berisi konsep atau topik yang cocok untuk sesi review, sebaliknya satu bagian kartu soal dan lainnya kartu jawaban; (2) Setiap siswa mendapat satu buah kartu; (3) Tiap siswa memikirkan jawaban/soal dari kartu yang dipegang; (4) Setiap siswa mencari pasangan yang mempunyai kartu yang cocok dengan kartunya (kartu jawaban); (5) Setiap pasangan siswa yang dapat mencocokkan kartunya 
sebelum batas waktu diberi poin; (6) Setelah satu babak kartu dikocok lagi agar tiap siswa mendapat kartu yang berbeda dari sebelumnya, demikian seterusnya; (7) Kesimpulan/penutup.

Jurnal penelitian Mediatati dan Ardhiyanto (2018) menyimpulkan adanya peningkatan hasil belajar siswa. Sebelum tindakan hanya 6 siswa $(23,08 \%)$ yang tuntas KKM . Setelah tindakan pada siklus I meningkat menjadi 20 siswa $(76,92 \%)$ tuntas KKM dan pada siklus II menjadi 26 siswa (100\%) tuntas KKM. Hasil penelitian ini dapat disimpulkan bahwa penggunaan model pembelajaran Make A Match dalam pembelajaran PKn dapat meningkatkan hasil belajar siswa.

Purnianingrum (2015) dalam penelitiannya menyatakan: 1) keterampilan guru siklus I memperoleh skor 28 dengan kriteria baik, siklus II memperoleh skor 32 dengan kriteria baik dan siklus III memperoleh skor 35 dengan kriteria sangat baik, 2) aktivitas siswa siklus I memperoleh rata-rata skor 21,7 dengan kriteria cukup, siklus II memperoleh rata-rata skor 25,13 dengan kriteria baik dan siklus III memperoleh rata-rata skor 28,21 dengan kriteria baik, 3) hasil belajar siswa dengan ketuntasan klasikal siklus I $63 \%$, siklus II 76,32\% dan siklus III 86,84\%. Simpulan penelitian ini membuktikan model make a match berbantuan media kartu bergambar dapat meningkatkan kualitas pembelajaran PKn meliputi keterampilan guru, aktivitas siswa dan hasil belajar siswa.

\section{METODE PENELITIAN}

Penelitian ini termasuk jenis Penelitian Tindakan Kelas (PTK) atau Classroom Action Research. Penelitian Tindakan Kelas (PTK) ini digunakan untuk menerapkan metode Make A Match untuk meningkatkan kompetensi belajar PPKn materi Pembukaan UUD 1945 pada siswa kelas IX SMP Negeri 3 Colomadu Karanganyar. Karakteristik PTK yang digunakan dalam penelitian ini adalah menggunakan siklus. Menurut Subyantoro (2018: 15), cyclus (siklus) adalah konsep tindakan pada dasarnya diterapkan melalui urutan-urutan planning, action-observing, and reflecting. Secara siklus yang ada hakikatnya menggambarkan pemikiran kritis dan reflektif terhadap efek tindakan. Dampak suatu tindakan tersebut selalu diikuti secara kritis dan reflektif.

Tempat penelitian ini adalah di SMP Negeri 3 Colomadu Kabupaten Karanganyar. Pelaksanaan penelitian adalah pada semester 1 tahun pelajaran 2019/2020 yaitu bulan Agustus 2019 sampai dengan bulan Oktober 2019. Subjek penelitian yang menerima tindakan adalah siswa kelas IX SMP Negeri 3 Colomadu tahun pelajaran 2019/2020. Kompetensi belajar siswa khususnya pada kompetensi sikap, pengetahuan, dan keterampilan perlu ditingkatkan. Subjek yang melaksanakan tindakan adalah guru mata pelajaran PPKn SMP Negeri 3 Colomadu.

Data dikumpulkan dengan menggunakan tes, observasi, kuesioner (angket), wawancara, dan dokumentasi. Teknik analisis data menggunakan analisis deskriptif komparatif dan teknik analisis kritis. Teknik analisis deskriptif komparatif digunakan untuk data kuantitatif yakni untuk membandingkan kompetensi belajar antarsiklus. Sedangkan teknik analisis kritis mencakup kegiatan untuk mengungkap kelemahan dan kelebihan yang muncul terkait dengan interaksi guru dan siswa dalam proses pembelajaran. 


\section{HASIL DAN PEMBAHASAN}

Proses pembelajaran PPKn di kelas IX B SMP Negeri 3 Colomadu khususnya pada materi Pembukaan UUD 1945, guru mengalami suatu permasalahan yaitu kurangnya kurangnya keaktifan dan kurangnya kompetensi siswa. Hal tersebut dapat dilihat dari pencapaian kompetensi belajar yang rendah, khususnya pada kompetensi pengetahuan yang masih lebih rendah dari KKM. Dari 32 orang siswa, sebagian besar siswa atau 90,6\% memiliki kompetensi pengetahuan yang belum mencapai KKM, sedangkan siswa yang mencapai KKM hanya 9,4\%. Pada kondisi awal, kompetensi pengetahuan siswa hanya mencapai rata-rata 60,7, lebih rendah dari KKM.

Sebagian besar siswa atau 65,6\% memiliki kompetensi sikap yang kurang aktif, siswa yang bersikap cukup aktif sebanyak $28,1 \%$, sedangkan siswa dengan kompetensi sikap yang aktif hanya mencapai 6,3\%. Kompetensi sikap siswa pada kondisi awal hanya mencapai rata-rata 1,8 (kurang aktif). Sebagian besar siswa mempunyai kompetensi sikap yang kurang aktif. Sebagian besar siswa atau 53,1\% memiliki kompetensi keterampilan yang cukup baik, siswa yang memiliki kompetensi keterampilan yang kurang baik sebanyak 40,6\%, sedangkan siswa dengan kompetensi keterampilan yang baik hanya mencapai 6,3\%. Kompetensi keterampilan siswa pada kondisi awal hanya mencapai rata-rata 55,3 (kurang baik).

\section{Siklus I}

Tahap pelaksanaan tindakan siklus I dilakukan pada hari Senin, 26 Agustus 2019, jumlah siswa yang hadir pada kelas IX B adalah 32 siswa. Kegiatan inti dimulai dengan menjelaskan materi pelajaran tentang Pembukaan UUD 1945 secara singkat. Selanjutnya guru memperkenalkan secara garis besar bagaimana model pembelajaran Make A Match. Guru menjelaskan langkah-langkah model pembelajaran menggunakan model Make A Match. Setelah dijelaskan, guru membagi siswa ke dalam 5 kelompok kecil. Mereka diberi batasan waktu untuk mendalami materi sekitar 10-20 menit. Guru kemudian melakukan pengocokkan kartu dan membagikan semua kartu kepada setiap siswa. Masing-masing siswa mendapat satu buah kartu soal atau kartu jawaban. Setelah semua siswa mendapatkan kartu, tiap siswa memikirkan jawaban/soal dari kartu yang dipegangnya dan menuliskan jawabannya ke buku dalam jangka waktu 2 menit.

Selanjutnya guru meminta semua siswa untuk maju dan saling berhadap-hadapan menjadi dua baris yaitu barisan pemegang kartu pertanyaan dan barisan pemegang kartu jawaban. Barisan pemegang kartu jawaban diminta menyebutkan kartu yang mereka miliki secara berurutan dari kanan ke kiri. Setelah itu, guru memberikan aba-aba pada setiap siswa untuk mencari pasangan dari kartu yang dimilikinya. Guru memberikan batasan waktu kepada siswa untuk menemukan pasangan dari kartu yang dibawanya. Setiap siswa yang dapat mencocokkan kartunya sebelum batas waktu dan benar diberi poin. Dalam hal ini, guru memberikan waktu selama 2 menit.

Setiap siswa mencari pasangan kartu yang cocok dengan kartunya (soal atau jawaban) dalam ruang lingkup pasangan kartu soal dengan kartu jawaban. Setiap siswa yang sudah 
menemukan pasangannya diminta untuk berada di sebelah kanan guru dan yang belum berada di sebelah kiri. Setelah pencocokan semuanya ada 4 orang siswa atau 2 pasang yang jawabannya belum cocok dan saling tertukar sehingga mereka diberi hukuman berupa mencocokkan lagi dengan batas waktu yang ditentukan oleh guru. Setelah semua siswa menemukan pasangannya, guru meminta siswa menunjukkan masing-masing kartunya dan kartu pasangannya kemudian dikonfirmasi bersama-sama apakah kartu pertanyaan dan jawaban yang mereka miliki cocok atau tidak.Setelah permainan selesai, guru meminta siswa untuk mengumpulkan kartu-kartu make a match dan siswa kembali duduk di tempat masing-masing. Selanjutnya siswa bersama guru menyimpulkan materi yang telah dipelajari hari ini.

Kegiatan akhir dilakukan dengan cara guru kembali mengkonfirmasi soal dan jawaban yang dipresentasikan siswa, kemudian melakukan refleksi dan selanjutnya siswa diberikan soal evaluasi terdiri dari 10 pertanyaan jenis uraian.

\section{Siklus II}

Tahap pelaksanaan tindakan siklus II dilakukan pada hari Sabtu, 7 September 2019, jumlah siswa yang hadir pada kelas IX B adalah 32 siswa.Kegiatan inti dimulai dengan menjelaskan materi pelajaran tentang Pembukaan UUD 1945 secara singkat. Selanjutnya siswa dibagi kedalam 5 kelompok, satu kelompok beranggotakan 4 orang siswa. Setelah itu siswa diminta untuk duduk berkelompok dan dibagikan materi tentang Pembukaan UUD 1945. Siswa diminta untuk mendalami materi yang sudah disediakan.

Siswa diberikan waktu sekitar 10 menit untuk memperdalam materi yang dipelajari dan meminta siswa dalam kelompok yang sudah paham untuk mengajarkan kepada teman dalam kelompoknya yang masih belum paham. Setelah batas waktu yang ditentukan selesai, guru meminta siswa untuk kembali duduk di tempat masing-masing. Kemudian, guru membagi kelas kedalam dua kelompok besar, kelompok pertama duduk dalam tempat duduk bagian kanan dan sebagian siswa duduk disebelah kiri. Guru membagikan kartu secara acak kepada masing-masing siswa, dan setiap siswa mendapatkan satu buah kartu. Selanjutnya guru memberikan waktu kepada siswa selama 5-10 menit untuk memikirkan jawaban yang cocok dengan kartu yng dibawanya.

Setelah batas waktu berpikir selesai, guru memberikan aba-aba kepada semua siswa untuk berdiri dan langsung menemukan pasangan kartu yang cocok dari kartu yang dibawanya. Semua siswa terlihat bersemangat dan saling beradu cepat untuk menemukan pasangan kartunya, sehingga suasana kelas menjadi sedikit gaduh. Setelah waktu yang ditentukan sudah habis guru meminta siswa untuk menghentikan pencarian dan diam ditempat. Kemudian guru mengecek siswa yang sudah menemukan pasangannya dan yang belum. Selanjutnya semua siswa diminta menunjukkan kartu yang dimilikinya dan pasangannya dan dibacakan di depan kelas.

Pada siklus II ini semua siswa sudah benar dalam mencocokkkan kartu pertanyaan dan jawaban, sehingga guru tinggal memberikan konfirmasi saja. Guru memberikan penghargaan kepada semua siswa dengan mengajak bertepuk tangan bersama dan memuji mereka dan berkata "Kalian semua pintar-pintar!" Satu-satu setiap pasangan kartu 
dipresentasikan apakah kartu pertanyaan dan jawaban yang mereka miliki cocok atau tidak. Setelah permainan selesai, guru meminta siswa untuk mengumpulkan kartu-kartu make a match dan siswa kembali duduk di tempat masing-masing. Selanjutnya siswa bersama guru menyimpulkan materi yang telah dipelajari hari ini.

Kegiatan akhir dilakukan dengan cara guru kembali mengkonfirmasi soal dan jawaban yang dipresentasikan siswa, kemudian melakukan refleksi dan selanjutnya siswa diberikan soal evaluasi terdiri dari 10 pertanyaan jenis uraian.

Berdasarkan hasil pelaksanaan pembelajaran dengan metode Make A Match selama 2 siklus, dapat diketahui adanya peningkatan kompetensi belajar siswa. Berikut ini tabulasi hasil peningkatan kompetensi belajar siswa kelas IX B SMP Negeri 3 Colomadu.

Tabel 1. Rekapitulasi Kompetensi Belajar PPKn pada Siswa Kelas IX B SMP Negeri 3 Colomadu Setelah Penerapan Metode Pembelajaran Make A Match

\begin{tabular}{|c|c|c|c|}
\hline Kompetensi & Kondisi Awal & Siklus I & Siklus II \\
\hline Pengetahuan & 60,7 & 79,5 & 85,8 \\
\hline Peningkatan (\%) & - & 30,9 & 7,9 \\
\hline Sikap & 1,8 & 2,4 & 3,4 \\
\hline Peningkatan (\%) & - & 36,0 & 42,1 \\
\hline Keterampilan & 55,3 & 71,9 & 89,1 \\
\hline Peningkatan (\%) & - & 30,0 & 23,9 \\
\hline
\end{tabular}

Kompetensi pengetahuan siswa pada kondisi awal hanya mencapai rata-rata 60,7 kemudian pada siklus I meningkat menjadi 79,5 dan pada siklus II mencapai rata-rata 85,8, sudah melebihi indikator kinerja yang ditetapkan yaitu sebesar 80, sehingga penelitian tindakan ini dinyatakan sudah berhasil. Kompetensi sikap siswa pada kondisi awal hanya mencapai rata-rata 1,8 kemudian pada siklus I meningkat menjadi 2,4 dan pada siklus II mencapai rata-rata 3,4 (sikap aktif). Kompetensi keterampilan siswa pada kondisi awal hanya mencapai rata-rata 55,3 kemudian pada siklus I meningkat menjadi 71,9 dan pada siklus II mencapai rata-rata 89,1, sudah melebihi indikator kinerja yang ditetapkan yaitu sebesar 80, sehingga penelitian tindakan ini dinyatakan sudah berhasil. Pencapaian indikator kinerja pada siklus II ini menunjukkan bahwa penerapan metode pembelajaran Make A Match efektif dalam meningkatkan kompetensi belajar siswa.

Peningkatan kompetensi belajar yang dicapai pada setiap akhir tindakan menunjukkan bahwa terdapat perubahan yang cukup signifikan antara prasiklus, siklus I dan siklus II dengan ketuntasan kriteria minimal (KKM) yaitu 80 di SMP Negeri 3 Colomadu. Hasil ini menunjukkan bahwa proses pembelajaran dengan menggunakan metode Make A Match dapat meningkatkan kompetensi belajar siswa pada pelajaran PPKn serta menunjukkan keberhasilan dalam penelitian tindakan yang telah dilaksanakan.

Peningkatan kompetensi belajar pada tiap siklus dapat diketahui karena adanya peningkatan keterampilan proses pada pembelajaran yang dilakukan. Hal ini sehubungan dengan strategi Make A Match yang dilakukan. Ketika mulai dikenalkan dengan model pembelajaran make a match siswa terlihat mulai antusias dalam mengikuti kegiatan pembelajaran. Ketika model pembelajaran digunakan dan siswa dibagikan kartu kemudian 
diminta untuk mulai mencari pasangan kartu yang dimilikinya, mereka mulai terlihat bersemangat. Mereka berlari dan berebut untuk saling beradu cepat dalam menemukan pasangan kartu yang dibawanya.

Siswa nampak senang dan aktif dalam pembelajaran, siswa yang memegang kartu soal dan jawaban saling mencari pasangannya, setelah ketemu mendiskusikan dengan pasangannya dan mempresentasikan hasilnya. Siswa saling bertanya dan menjawab serta menanggapi jawaban, dan guru bertindak sebagai fasilitator dan meluruskan jawaban yang kurang tepat. Oleh karena siswa aktif sehingga dapat memahami materi dengan baik. Melalui strategi ini siswa merasa ditantang akan pemahaman yang didapatnya, dan menuntut siswa untuk aktif dan bertanggung jawab.

Sesuai dengan pendapat Lie (2010: 55) yang mengatakan bahwa pembelajaran Make A Match mempunyai keunggulan antara lain: dapat meningkatkan aktivitas belajar siswa, suasana pembelajaran menyenangkan karena ada unsur permainan, dapat meningkatkan pemahaman siswa terhadap materi yang dipelajari dan dapat meningkatkan motivasi belajar siswa. Melalui penerapan model pembelajaran Make A Match siswa dapat belajar mengenai suatu konsep dalam suasana menyenangkan dan bekerjasama dengan teman memahami materi yang disampaikan guru sehingga kompetensi belajar siswa meningkat.

Peningkatan kompetensi belajar ini menunjukkan bahwa siswa mulai memahami materi yang diajarkan secara mendalam. Sejalan dengan pendapat Huda (2014: 253) yang menyatakan bahwa salah satu kelebihan pembelajaran make a match adalah dapat meningkatkan motivasi belajar siswa. Hal tersebut terjadi karena dengan menggunakan model pembelajaran yang menyenangkan, dengan menggunakan kartu-kartu yang dibuat dan dikemas dengan menarik, siswa dapat lebih bersemangat dalam mengikuti kegiatan pembelajaran. Siswa merasa senang dan bersemangat, sehingga siswa bisa lebih mudah menguasai konsep yang sedang diajarkan.

\section{KESIMPULAN}

Kesimpulan penelitian ini adalah: Pelaksanaan pembelajaran dengan metode Make A Match dapat meningkatkan kompetensi belajar PPKn materi Pembukaan UUD 1945 pada siswa kelas IX SMP Negeri 3 Colomadu Karanganyar Semester 1 Tahun Pelajaran 2019/2020. Kompetensi pengetahuan siswa pada akhir siklus II mencapai rata-rata 85,8, sudah melebihi indikator kinerja yang ditetapkan yaitu sebesar 80. Kompetensi sikap pada akhir siklus II mencapai rata-rata 3,4 (sikap yang aktif) dan kompetensi keterampilan siswa pada akhir siklus II mencapai rata-rata 89,1 (sangat baik), sehingga penelitian tindakan ini dinyatakan sudah berhasil. Pencapaian indikator kinerja pada siklus II ini menunjukkan bahwa penerapan metode pembelajaran Make A Match efektif dalam meningkatkan kompetensi belajar siswa.

Saran untuk pihak sekolah, perlu menganjurkan kepada guru pengampu mata pelajaran lainnya untuk menerapkan model pembelajaran aktif Make A Match demi tercapainya kompetensi belajar siswa. Saran bagi guru PPKn, perlu memperbanyak pengetahuannya mengenai variasi metode pembelajaran. Hal ini akan membantu guru untuk dapat meningkatkan kualitas proses dan hasil belajar siswa dalam proses pembelajaran. Penggunaan metode pembelajaran Make A Match dapat menjadi alternatif peningkatan efektifitas pembelajaran. 
Guru diharapkan memberikan materi pembelajaran dengan variasi yang menarik sehingga dapat meningkatkan minat, motivasi dan partisipasi siswa untuk memahami materi yang disajikan sehingga dapat meningkatkan hasil belajar siswa.

Saran bagi siswa hendaknya lebih aktif dalam pembelajaran, mempunyai motivasi untuk belajar agar hasil pembelajaran dapat maksimal dan sesuai dengan harapan. Siswa harus selalu berperan aktif dalam kegiatan pembelajaran dan selalu bersedia dengan kesadaran sendiri untuk mengerjakan tugas-tugas yang diberikan guru.

\section{DAFTAR PUSTAKA}

Hamdayama, Jumanta. 2017. Metodologi Pengajaran. Jakarta: Bumi Aksara.

Huda, Miftahul. 2014. Model-Model Pengajaran dan Pembelajaran:Isu-Isu Metodis dan Paradigmatis. Yogyakarta: Pustaka Pelajar

Lie, Anita. 2010. Cooperatife Learning: Mempraktikkan Cooperative Learning di Ruang-Ruang Kelas. Jakarta: Gramedia Wisiasarana Indonesia

Mediatati, Nani dan Ardhiyanto, Ferditya. 2018. Meningkatkan Hasil Belajar Siswa Dalam Pembelajaran PKn Menggunakan Model Pembelajaran Make A Match di Kelas IX di SMP Negeri 7 Salatiga. Jurnal PKn Progresif, Vol. 13 No. 2 Desember 2018

Purnianingrum, Leny Shela. 2015. Peningkatan Kualitas Pembelajaran Pkn Melalui Model Make A Match Berbantuan Media Kartu Bergambar Siswa Kelas V SDN Karanganyar 02 Kota Semarang. Jurnal Jurusan Pendidikan Guru Sekolah Dasar Fakultas Ilmu Pendidikan Universitas Negeri Semarang

Rusman. 2014. Model-Model Pembelajaran, Mengembangkan Profesionalisme Guru. Depok: Rajawali Pers (Rajagrafindo Persada).

Subyantoto. 2018. Penelitian Tindakan Kelas: Metode, Kaidah Penulisan, dan Publikasi. Depok: Rajawali Pers (Rajagrafindo Persada).

Sumartini, Ai Tin dan Putra, Asep Sutisna. 2018. Pendidikan Pancasila dan Kewarganegaraan untuk SMP/MTs Kelas IX: Buku Guru. Jakarta: Kementerian Pendidikan dan Kebudayaan.

Suprijono, Agus. 2014. Cooperative Learning. Yogyakarta: Pustaka Pelajar.

Suwandi, Sarwiji. 2008. Penelitian Tindakan Kelas (PTK) dan Penulisan Karya Ilmiah. Surakarta: Panitia Sertifikasi Guru Rayon 13. 
Supanti / Edunomika Vol. 04 No. 01 (Februari 2020)

Trianto. 2008. Mendesain Pembelajaran Konstektual di Kelas. Jakarta. Cerdas Pustaka Publisher.

Yamin, Martinis. 2016. Kiat Membelajarkan Siswa. Jakarta: GP Press 